$\begin{array}{r}\text { Volume and Issues Obtainable at Center for Sustainability Research and Consultancy } \\ \text { Journal of Business and Social Review in Emerging Economies } \\ \text { ISSN: 2519-089X (E): 2519-0326 } \\ \text { Volume 6: No. 3, September 2020 } \\ \text { CSRᄃ } \\ \text { Journal homepage: www.publishing.globalcsrc.org/jbsee } \\ \hline\end{array}$

\title{
Assessment of Sustainable Competitive Advantages and Influences through Project Management Practices of Construction Industry of Pakistan
}

\author{
${ }^{1}$ Shahid Iqbal, ${ }^{2}$ Syed Farqaleet Kausar Bukhari, ${ }^{3}$ Abdur Rehman Riaz, ${ }^{4}$ Syed Arslan Haider \\ ${ }^{1}$ Assistant Professor, Management Studies Department, Bahria University Islamabad Campus, Pakistan, \\ siqbal.buic@bahria.edu.pk \\ ${ }^{2}$ MS student, Management Studies Department, Bahria University Lahore Campus, Pakistan, \\ syedfarqaleet@gmail.com
}

${ }^{3}$ MSC Student, Department of Management, University of Hertfordshire, College Lane, Hatfield, Hertfordshire, United Kingdom, abdur_rehman225@ hotmail.com

${ }^{4} \mathrm{PhD}$ Scholar, Department of Management, Sunway University Business School (SUBS), Sunway University, Selangor Darul Ehsan, Malaysia, haidershah24@gmail.com

\begin{tabular}{l}
\hline ARTICLE DETAILS \\
\hline History \\
Revised format: August 2020 \\
Available Online: September \\
2020
\end{tabular}

\section{Keywords}

Project Sustainability;

Construction Project Success;

Project managers leadership

competencies; $\quad$ SmartPLS

Analysis

JEL Classification

MO, M1

\section{ABSTRACT}

Sustainability and project managers leadership competencies both are the topics which have been undertaken for research by countless studies and authors. Therefore, this study aims at investigating the effects and consequences of the project sustainability on the construction sector project success through the moderating role of Project managers leadership competencies. Due to the deadly disease - COVID-19, there was no other option to collect the data so the online survey method has been used, from the construction companies having the project-based status throughout in Pakistan having sample size four hundred i.e. $\mathrm{n}=327$. Moreover "Random Sampling Technique" \& "Smartpls version three - 3" was used for the analyzation of our collected data. The overall results showed that the assumptions made are satisfied and the triple bottom-line aspects of sustainability have a major influence over the projects in Pakistan.

\section{OPEN ACCESS}

(C) 2020 Center for Sustainability Research and Consultancy Pakistan under a Creative Commons Attribution-NonCommercial-ShareAlike 4.0

Corresponding author's email address: siqbal.buic@ @ahria.edu.pk

Recommended citation: Iqbal, S., Bukhari, S. F. K., Riaz, A. R., \& Haider, S. A. (2020). Assessment of Sustainable Competitive Advantages and Influences through Project Management practices of Construction Industry of Pakistan. Journal of Business and Social Review in Emerging Economies, 6(3), 1199-1209

\section{Introduction}

Projects may do well and come up short with respect to how well they attain their goals and how they are regulated (Ul Musawir et al., 2017; de Melo et al., 2020). There is a desperate need to consolidate sustainability into project management to improve results and vital advantages over the long term (Hussain et al., 2020). Nowadays, sustainability is getting prestigious and organizations are making it a piece of their standard measures to get longer range benefits. The tripled main concern (TBL) viewpoint including environmental, social and economic impacts, empowers us to reevaluate our procedures to work with and accomplish more (Martens, Carvalho, 2017). Sustainability evaluations always need indisputable relevant information about the important element of sustainability present in the projects, subsequently provide guidance in the midst of the fundamental administration process in a way that is direct and far-reaching of each and every included assembling (Švajlenka \& Kozlovská, 2020). Researchers 
have investigated present issues in sustainability practices. They distinguish a necessity to set up a strategy for distinguishing and choosing a lot of pointers that represented with the project life cycle to discover a proper harmony between every single included performer (Falqi, Alsulamy \& Mansour, 2020). Sustainability has been projected by the researchers as an open of a new avenue/door for the development and through a successful execution of projects (Tan et al., 2020).However, this research explores the advantages of project monitoring while having sustainable project management incorporated as an organization's project. Although, the idea of project management incorporating sustainability in its domain is increasing in its significance in future. A lot of work has been done on the significance of fit in sustainability in the domain project management field. Though, the key influences of sustainability in project management based on its undeniable terminology, triple-element outlook having social, environmental and economic point of views, is the area that needs an intense research in order to achieve the key factors for a successful project, in a project manager's leadership competencies (PMLC) lens (Al Halbusi et al., 2017; Alvarenga et al.,2019). Therefore, there is a huge room for research to analyze the essential factors of sustainability in project-based construction organization of Pakistan.

Sustainability remains a subtle objective in Pakistan. While there has been plenty of approaches, systems, and outlines for economic advancement with self-important targets and hopeful courses of events, Pakistan experiences serious slacks in the usage of improvement designs, because of inadequate checking and blemishes in the assessment of projects (Rostamnezhad et al., 2020). Indeed, even in the private segment, the quantity of project-based construction organizations with very much characterized sustainability approaches and consciousness of sustainability revealing is low. Pakistan verified a notch of 55.6 under sustainable development goals (SDGs') overall rundown against a clearly enhanced local ordinary of sixty-three point three (63.3) and is even lesser than common partners and Bangladesh's fifty-six point two (56.2) and India's fifty-eight point one (58.1). In this manner, the country situated one hundred and twenty-two (122) on the SDG rundown of one hundred and fifty-seven (157) nations appeared in a different way in relation to Bangladesh's one hundred and twenty (120) and India's one hundred and sixteen (116) positions, according to July 2017 results (Aftab, Kamal \& Irfan, 2020).

Project the board and sustainability have been tended to by unlimited examinations, be that as it may, the intersection point between above mentioned fields is so far slim with just a few focuses that have focused on the two subjects. As revealed by Gimenez et al. (2012), "sustainability facilitates social, ecological, and monetary obligation to make prudent use of present resources and to offer conventional life for who and what is to come". There is a desperate need to consolidate sustainability into project management to improve results and vital advantages over the long haul. Currently, sustainability is getting prestigious and organizations are making it a piece of their standard measures to get longer range benefits. The tripled main concern (TBL) viewpoint including environmental, social and financial impacts, empowers us to reevaluate our procedures to work with and accomplish more (Martens et al. 2017; Qureshi et al., 2020). This study reconfigures the significance of essential factors enhancing sustainability in construction sector project and how its incorporation helps in project success through moderating role of project manager's management expertise. Over the span of ongoing years, business associations have been hunting down ways to deal with join sustainability outlooks in their promotions, communal trades, yearly inform in their reports, and exercises whichever dynamically or responsively. A gap is still found between recommended and not recommended features in the literature and completed works practically speaking (Aureli et al., 2020). The sustainability is dynamically observed as crucial for considering the social, financial and ecological outcomes identified with the way in which ventures and their assistance frameworks are composed, made, worked and kept up. In this setting, sustainability is transforming into an accentual bit of all project masterminding frameworks (Hussain et al., 2020). The literature will be a base to recognize the importance of sustainability intervention in project management.

\section{Literature Review}

\subsection{Project Sustainability and Construction Project Success}

An investigation coordinated in 2002 by Price-water-house-Coopers on sustainability, referred to by means of Carvalho \& Rabechini Jr. (2017), demonstrate that the joining of sustainability points of view into projects addresses a considerable role in the management of associations. The basic need to move in the direction of sustainability by establishing the three parts of sustainability which are ecological, social and financial into the project management at 
a utilitarian measurement is clear (Yu et al., 2018). The reports issued by these authors about social and ecological components of sustainability are sometimes disregarded, anyway it is the social estimation that is oftentimes rejected. On the other hand, project management and sustainability can be manhandled in a couple of conducts, and associations that consider sustainability to be a very important element of their business \& that work sustainability into the enhancement and management of projects should know about going with recommended methods: having sustainable acquire products, rising an orderly project arrangement, using project life-cycle examination, executing project hazard management, and project game plan while involving sustainability elements (Zaman et al., 2020).

\subsection{Economic Aspects of Sustainability and Construction Project Success}

At the organizational dimension, corporate social obligation enhances environmental and economic accomplishment. At this dimension, a triple element idea (social, environmental and economic) turns out to be progressively plausible and important (Narimissa et al., 2020). A few investigations have demonstrated that socially capable organizations additionally make a move, at any rate for the time being. Besides, it is usual that in the long run social solidarity will be the priority of the related organizations. Consequently, the most important part is that the three (03) elements of the "triple-bottom line" outlook have been put into a structure of developments, components, or the features which can be exploited as an optimal model by establishments that desire the sustainability to be enhanced. The canons of financial aspects of environmental and related procedures have been entrenched, and environmental activities are seen to significant development (Nesticò\& Maselli, 2020). The engrained principles, for example, "Leadership in Energy and Environmental Design" (LEED) prerequisites are outstanding in the structure business (El Garhy et al., 2020). Sustainability having economy as a component is imperative since it ensures the speculator's capital(Zia-ur-Rehman, $\&$ Zia,2020). In any case, in this unique situation, the social and environmental measurements ought to likewise be advanced. For instance, the utilization of these two measurements may expand project effectiveness through better acquiring, increasingly viable utilization of assets, the utilization of clean innovations and sustainable power source, lessening the utilization of petroleum derivatives, and so on.

\subsection{Environmental Aspects of Sustainability and Construction Project Success}

At the organizational dimension, corporate social obligation enhances environmental and financial execution. Here in this point of view, a triple element vision including social, economic and environment turns out to be progressively attainable and important. A few investigations have demonstrated that socially capable organizations additionally make a move, at any rate temporarily. Besides, it is normal that social solidarity will be kept on priority by these organizations eventually (Alintah-Abel, Iheama \& Ugochukwu, 2020).In this manner, it is basic that the estimations of the main tri-element aspects are involved into a structure of development, components, or elements that can be used as a choice of standard by associations that longing to upgrade the sustainability. The principles of ecological monetary viewpoints and related strategies have been settled, and natural exercises are seen to generous development (Ahuja et al., 2019).

\subsection{Social Aspects of Sustainability and Construction Project Success}

The ramifications of actualizing a social sustainability point of view have once in a while been talked about. It was contended that a project with real sustainable development, for instance, must incorporate social observations about the user, just as review of the project effects in the network with respect to the security, wellbeing, and instruction of individuals included (Montalbán-Domingo et al., 2019). These observations when coordinated would eventually enhance the execution of long-term projects and also the personal satisfaction of individuals influenced by those projects. In this way, as indicated (Sarkis and others-2012), the fundamental tri-elements parts of the triple-bottom method must be additionally talked about, displayed and comprehended. At the point when a triple-element method is utilized, the social environmental and economic parts of a project are incorporated in a better way. Many factors of sustainability and markers are compulsory to construct this combination progressively plausible (Alvarenga et al., 2019). 


\section{H1: Project sustainability is positively associated construction project success.}

\section{Project Managers Leadership Competencies as Moderator Between Project Sustainability and Construction Project Success}

The capabilities of the project manager (as a leader) has been recognized as a main driving force for any organization's achievement, particularly in vibrant working environment (Al Halbusi et al., 2017). On the basis of many research studies/theories (Al Halbusi et al., 2018; Alvarenga et al.,2019). The lacking of leadership within the project performance had been seen one of the big problems for both industry \& academia(Chow et al., 2017), and the same had been confirmed in numerous research studies (Ahmed \& Anantatmula, 2017; Halbusi et al., 2018). Furthermore, the project manager ought to believe about the results that sustainability courses of action $\&$ controls may have an effect on the project. Sustainability thoughts are seen as outside to the basic project, yet may be consolidated, as project accomplishment will be evaluated according to the association's methodologies. "Hueman 21 and Eskerod have researched what "PRINCE2", the "PMbok Guide18" and the "ICB International Competence Baseline 3.023" state about accomplice issues and sustainability" (Økland, 2015). Its reasons that neither of the three clearly considers sustainability issues.

The worldwide institutionalization organization (ISO) is taking a shot at another arrangement of measures for sustainability and flexibility, starting with ISO 371001 (Gomez-Gutierrez \& Cormier, 2019). It isn't straightforwardly tending to project management, in spite of the fact that the emphasis on management frameworks may be relevant to projects too. The particular goal and picked targets are the basis on which the projects are selected and executed. Despite the triple constraint of projects which is described as scope, cost and time, project managers are dynamically worried about a project's progressively broad points of interest and regard (Lozano \& Garcia, 2020). The essential factors of a project can be considered similar to various social, ecological, and financial estimations that are featured in sustainability. Advantages, esteem, and repute creation may deduce assorted things to the project authoritative laborer and the customer and show up contrastingly in the midst of the unmistakable times of the project's and the thing's life cycle, therefore making the assurance of project goals testing(Haider, \& Kayani, 2020).

\section{H2: Project managers leadership competencies positively moderate the relationship between Project Sustainability and construction project success.}
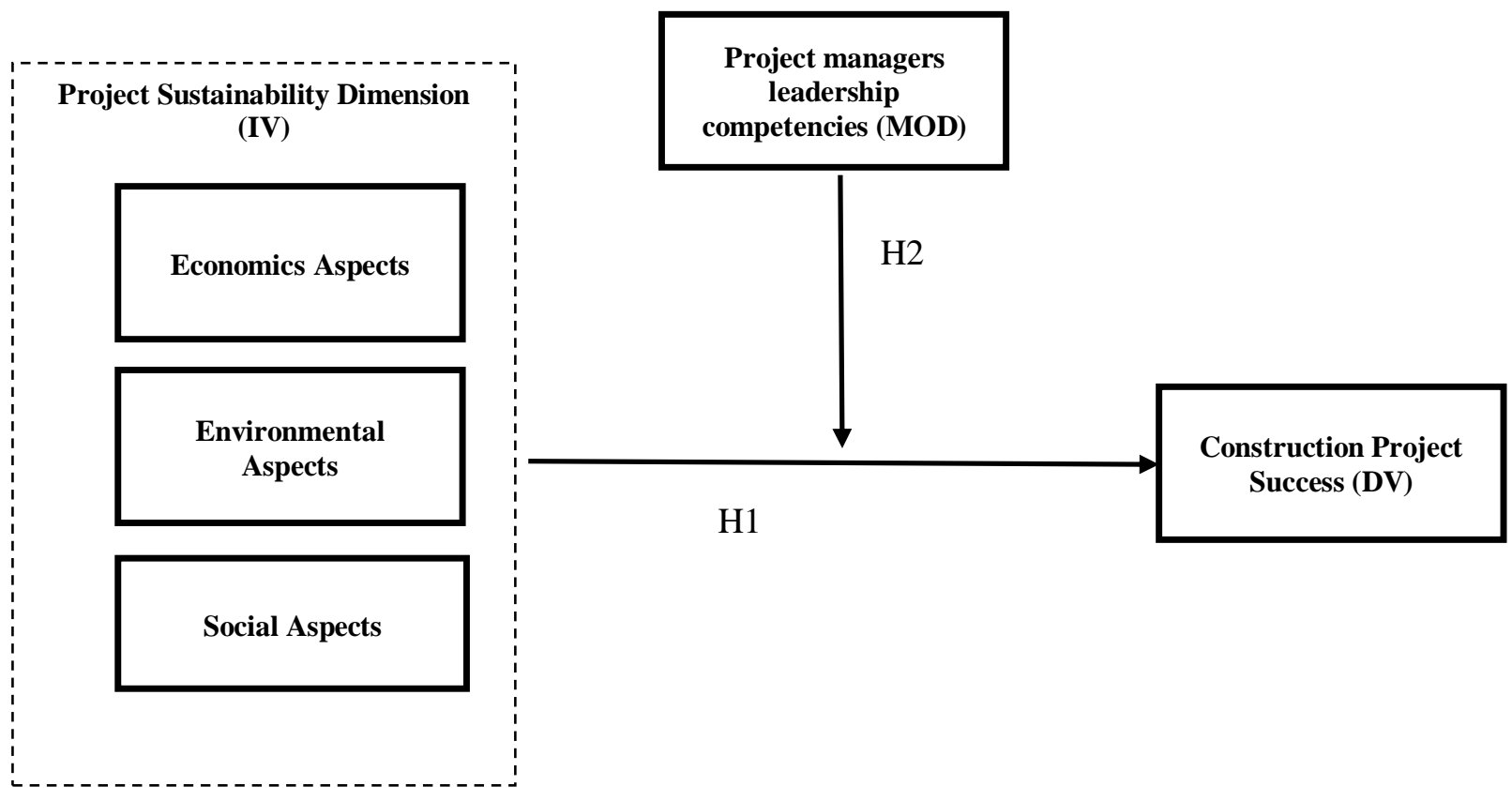


\section{Research Design \& Sampling Method}

The assortment of data from the whole populace isn't possible because of asset and time imperative, which is the motivation behind why inspecting is utilized to gather and analyze information. Thusly, in this investigation an example arbitrary procedure was utilized to gather information in light of the fact that both decrease the regular strategy change from the information assortment measure (Trivedi, 2017). Consequently, the number of inhabitants in this exploration incorporates diverse public and private task-based development organizations of Pakistan (Habib Rafiq, Defense Housing Authority, and Bahria Town) working in various urban areas Islamabad, Rawalpindi, Lahore and Karachi. The principal creator visited these associations and got authorization of the workers to partake in the examination, because of COVID-19 information additionally been gathered on the web. A total of 400 reviews were passed on and 327 members restored the survey. The reaction rate was very reassuring in such troublesome COVID19-time span, yielding a reaction pace of $81.75 \%$. After information assortment Harman's single factor test is led to distinguish normal strategy difference the consequence of extraction amounts of squared stacking $24.38 \%$ of fluctuation which is under half, which implies there is no basic technique one-sided issue in information (Tehseen, Ramayah and Sajilan, 2017).

Out of these respondents, $70.6 \%$ were male and $29.4 \%$ were female, as the presence of ladies in development ventures in Pakistan is very low. Most of the example fell inside the ages of 18-33 years of age. As for the instructive level huge quantities of respondents are four-year certification holders. In Pakistan, venture-based development organizations have as of late began employing new graduated individuals. Additionally, the respondents of current examination had greater part work residency of 1-5 and 6-10 years. The items are responded at 5-points Likert-scale where 1 (strongly disagree) to 5 (strongly agree) as suggested by Lumpkin (1985). The questionnaire consisted of 38items in total. Independent variable Project Sustainability based on three-dimensioneconomics aspects (3-items), environmental aspects (8-items) and social aspects (11-items) adapted from Martens \& Carvalho (2017), 9-items moderating variable Project managers leadership competencies (PMLC) (Dulewicz \& Higgs, 2005), dependent variable Construction Project Success (CPS)(U1 Musawir et al., 2017). PLS-SEM technique was chosen to analyze the data because this study aimed to predict the key construct and new relationships (i.e. moderating) were involved in this study (Hair et al., 2016).

\section{Research Findings}

The assessment was set up utilizing WarpPLS to examine the impacts of factors announced in the examination theories. There are a few necessities while performing examination in WarpPLS; those must be first satisfied concerning different fit models and quality lists, guaranteeing that the instrument is solid (Kock, 2017). The results of the assessment have uncovered that all fit model estimations have met the normalized measures; great, huge, and ideal as appeared in Table 1. Additionally, basic before reexamining the legitimacy and dependability of the surveys including Cronbach's alpha $(\alpha)$, composite reliability (CR) and average variance extracted (AVE). The hypothesis legitimacy of explicit indicators can be evaluated by inspecting the particular and factor loadings, where it has been suggested that a loading, of $>0.50$ on two or more factors is reflected significant (Hair et al., 2014).

Table 1: Model fit and quality indices

\begin{tabular}{|c|c|c|c|c|}
\hline No & $\begin{array}{l}\text { Model fit and quality } \\
\text { indices }\end{array}$ & Criteria fit & Results & Remarks \\
\hline 1 & $\begin{array}{c}\text { Average path } \\
\text { coefficient (APC) }\end{array}$ & $\mathrm{P}<0.001$ & 0.417 & Good \\
\hline 2 & $\begin{array}{c}\text { Average R-squared } \\
\text { (ARS) }\end{array}$ & $\mathrm{P}<0.001$ & 0.678 & Good \\
\hline 3 & $\begin{array}{l}\text { Average adjusted R- } \\
\text { squared (AARS) }\end{array}$ & $\mathrm{P}<0.001$ & 0.676 & Good \\
\hline 4 & $\begin{array}{c}\text { Average block VIF } \\
\text { (AVIF) }\end{array}$ & $\begin{array}{c}\text { acceptable if }<=5 \text {, ideally } \\
<=3.3\end{array}$ & 1.074 & ideally \\
\hline 5 & $\begin{array}{c}\text { Average full } \\
\text { collinearity VIF } \\
\text { (AFVIF) }\end{array}$ & $\begin{array}{c}\text { acceptable if }<=5 \text {, ideally } \\
<=3.3\end{array}$ & 2.174 & ideally \\
\hline
\end{tabular}




\begin{tabular}{|c|c|c|c|c|}
\hline 6 & Tenenhaus GoF (GoF) & $\begin{array}{c}\text { small }>=0.1, \text { medium }>= \\
0.25, \text { large }>=0.36\end{array}$ & 0.689 & large \\
\hline 7 & $\begin{array}{l}\text { Sympson's paradox } \\
\text { ratio }(\mathrm{SPR})\end{array}$ & $\begin{array}{c}\text { acceptable if }>=0.7, \\
\text { ideally }=1\end{array}$ & 1.000 & ideally \\
\hline 8 & $\begin{array}{c}\text { R-squared } \\
\text { contribution ratio } \\
(\mathrm{RSCR})\end{array}$ & $\begin{array}{c}\text { acceptable if }>=0.9, \\
\text { ideally }=1\end{array}$ & 1.000 & ideally \\
\hline 9 & $\begin{array}{c}\text { Statistical suppression } \\
\text { ratio }(\mathrm{SSR})\end{array}$ & acceptable if $>=0.7$ & 1.000 & ideally \\
\hline 10 & $\begin{array}{l}\text { Nonlinear bivariate } \\
\text { causality direction } \\
\text { ratio (NLBCDR) }\end{array}$ & acceptable if $>=0.7$ & 0.900 & ideally \\
\hline
\end{tabular}

Subsequently, Table 2 shows the consequences of three builds including venture supportability, venture administrator's authority capabilities and development venture achievement are largely legitimate proportions of their specific develops. Since, Fornell and Larcker said that if AVE is under 0.5, anyway composite unwavering quality is higher than 0.6, the concurrent legitimacy of the build is as yet worthy (Fornell and Larcker, 1981). Consequently, all assessments of factor loadings, CR and AVE are more noteworthy than the recommended cut off standards; in this way, Table 2 indicated the estimation model has a merged legitimacy. In the wake of affirming the concurrent legitimacy of the model that met the pre-set rules, the ensuing advance was to certify the model's discriminant legitimacy is assessed by utilizing Fornell and Larcker's standard (Fornell and Larcker, 1981). As indicated by this measure, the square base of AVE for each dormant variable ought to be more prominent than the estimations of its bivariate relationships (Ringle et al., 2015). The connections of idle factors in Table 2 uncovered the inactive develops are particular from one another.

Table 2: Discriminant validity

\begin{tabular}{cccccccc}
\hline Constructs & $\mathbf{A}$ & $\mathbf{C R}$ & $\mathbf{A V E}$ & $\mathbf{1}$ & $\mathbf{2}$ & $\mathbf{3}$ & $\mathbf{4}$ \\
\hline PSD & 0.851 & 0.958 & 0.527 & 0.821 & 0.726 & 0.108 & 0.067 \\
CPS & 0.886 & 0.909 & 0.675 & 0.726 & 0.822 & 0.187 & 0.046 \\
PMLC & 0.831 & 0.820 & 0.601 & 0.108 & 0.187 & 0.775 & 0.379 \\
PMLC*PSD & 1.000 & 1.000 & 1.000 & 0.067 & 0.046 & 0.379 & 1.000
\end{tabular}

Notes: ${ }^{\mathbf{a}}$ The Items displayed in boldface represents the square roots of the AVE. Abbreviations: Project sustainability Dimension (PSD); project managers leadership competencies (PMLC); construction project success (CPS);Cronbach's alpha ( $\alpha$ ); Composite reliability (CR); Average variances extracted(AVE).

The structural equation model is processed after estimation model is finished. To analyze the directing results venture administrators' initiative skills, we followed the techniques suggested by Henseler et al. (2015). To break down both the immediate and roundabout impacts of the auxiliary condition models, four explicit measures were utilized:Firstly, estimating the level of R2, for endogenous latent variables to determine the amount of variance elucidated by all constructs (Hair et al., 2016). Although, the satisfactory assessment of R2 depends on the study setting (Faul et al., 1998) displays the assessment of $0.26,0.13$, and 0.09 shows high, moderate and low, respectively. However, in current study R2 values for endogenous variable, the direct effect model elucidated construction project success is 0.678, which implies that $67.8 \%$ change of CPS is predicted by PSD and PMLC. The model shows high predictive accuracy as shown in Figure 2.Secondly, determining the predictive relevance (Q2) a cross-validation redundancy measure was also used to measure the appraised significance of the investigation model (Hair et al., 2014). Table 3 shows the adequate estimations significance of the indirect effect model because value of Q2 greater than zero,the indirect effect of PSD and PMLC on CPS is Q2 $=0.686$ which is greater than zero, it can be considered as an acceptable predictive relevance of the model (Henseler et al., 2015). 


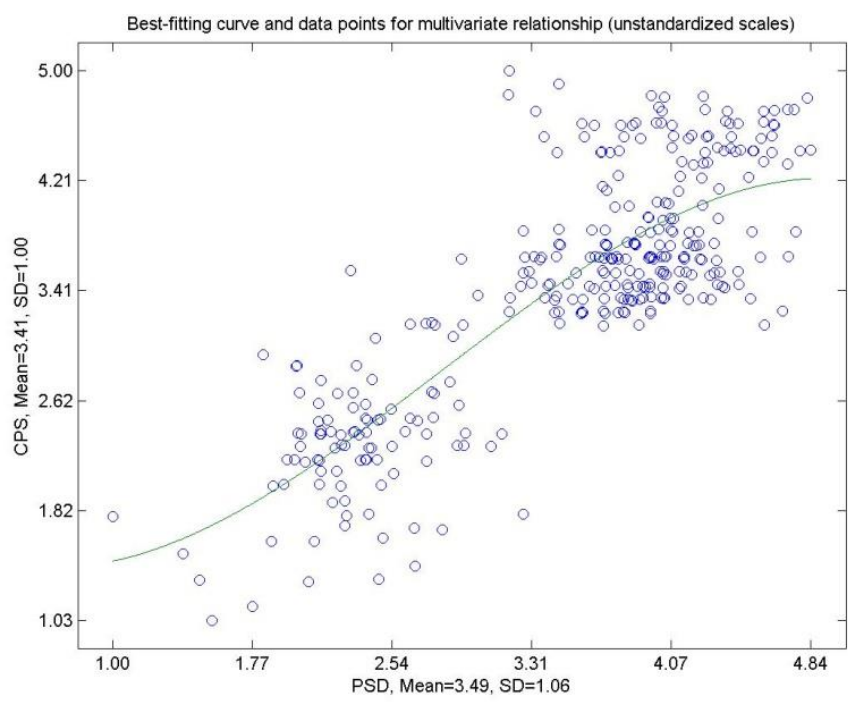

Figure 2: Direct effect of PSD on CPS

Table 3: Coefficient of Determination in the PLS method

\begin{tabular}{lccc}
\hline Construct & R Square & R Square Adjusted & $\mathrm{Q}^{2}$ \\
\hline CPS & 0.678 & 0.676 & 0.686 \\
\hline
\end{tabular}

Thirdly, effect size (f2) is the effect by independent variable explicit to the dependent variable in order to perceive how large the effect of exogenous (independent variable) is obvious to endogenous (dependent variable) (Hair et al., 2014). According to the Faul et al. (1988) rule, the effect size estimates between 0.02, 0.15 and 0.35 as having small, medium and large effects, correspondingly. Table 4 specifies effect size 0.680 for PSD to CPS, 0.269 for an PSD*PMLC to CPS. The result directs large effect size of these exogenous constructs on the endogenous construct, respectively. Finally, Result indicates $\mathrm{H} 1$ the direct effect of PSD is significant and positive effect on CPS ( $\beta=0.823$, $\mathrm{p}<0.001)$. As described in Figure 3, the moderating effect of both PMLC is positive and significant as presented in Figure 4. Therefore, the hypotheses $\mathrm{H} 1$ and $\mathrm{H} 2$ were accepted.

Table 4: Path coefficient direct effect and indirect effect

\begin{tabular}{llcccc}
\hline Hypothesis & Constructs relationships & $\boldsymbol{\beta}$ & P Values & $\mathbf{f}^{2}$ & Remarks \\
\hline H1 & PSD ->CPS & 0.823 & $<0.001$ & 0.680 & Supported \\
H2 & PSD*PMLC ->CPS & 0.255 & $<0.010$ & 0.269 & Supported \\
\hline
\end{tabular}




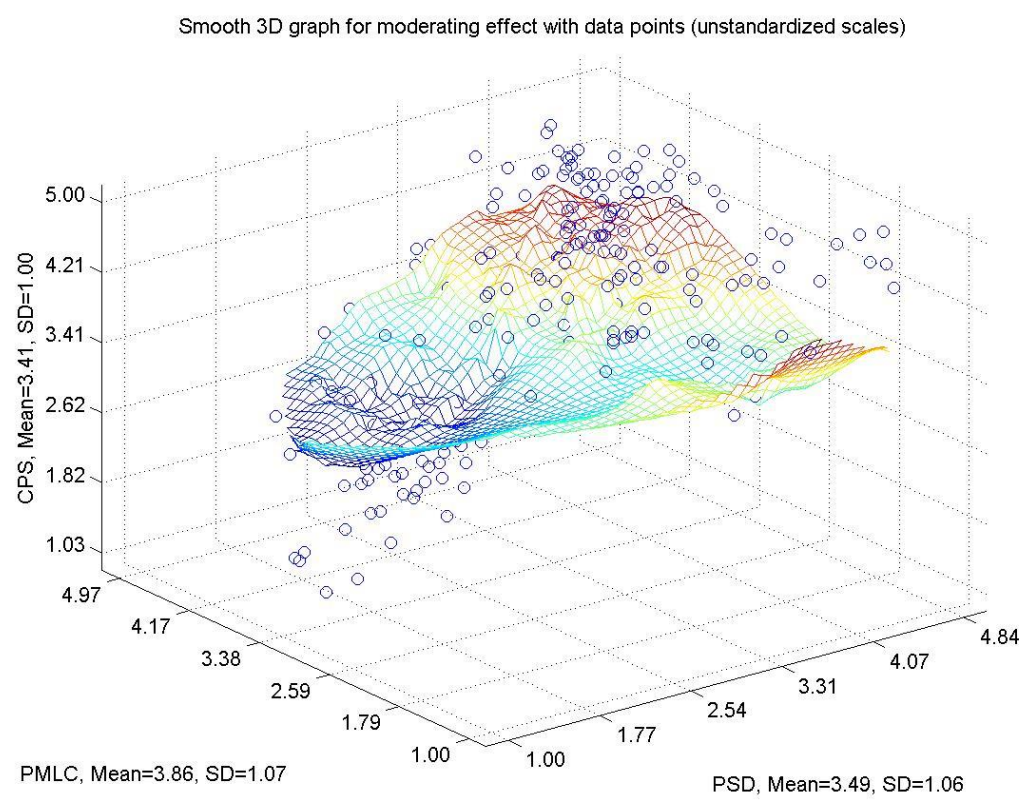

\section{Discussion}

Figure 3: Moderating of PMLCon PSD and CPS

According to Ul Musawir et al. (2017), the connection between project management and sustainability is quickly picking up enthusiasm from experts and scholastics. Concentrates on the combination of sustainability ideas into the management of projects for the most part address the subject from a theoretical, sensible, or on the other hand moral perspective(Lozano et al., 2020). Given that the connection between sustainability and project management is as yet a developing field of study, these methodologies bode well. Notwithstanding, the discoveries of our examination don't nullify the requirement for increasingly observational investigations to see how the ideas of sustainable advancement can be actualized in project management field.As indicated by Gimenez et al. (2012), the principle parts of the triplemain concern approach in projects and project management must be additionally talked about, displayed, and comprehended. At the point when a triple-primary concern approach is utilized, the monetary, natural, and social parts of a project are better coordinated. A lot of sustainability factors and markers is required to make this coordination progressively achievable (Montalbán-Domingo et al., 2019; Alintah-Abel et al., 2020; Narimissa et al., 2020).

\subsection{Recommendations for Future Research}

It is obvious for such big business sustainability requirements are to take account of the amalgamation of the objective of sustainable progression, social value, monetary expertise, and accepted implementation into the prepared practices and projects of any company/organization. Organizations that contend comprehensively progressively need to focus on being educated about the worldwide sustainability exhibitions of operational activities. The present systems of factors and pointers accessible to measure the general sustainability of business don't bargain successfully with all parts of sustainability at the operational level, particularly in creating nations. Future research concentrating on the validation and organizing sustainability develops and factors inside a triple-bottom line framework would be valuable. Advanced field researches investigating these elements in case studies ought to be fascinating. In addition, different surveys investigating unforeseen factors as divisions and nations could be performed.

\subsection{Limitations of the Study}

Moreover, there are significant difficulties in creating asset related projects that meet the beliefs of sustainability. The standards and arrangements of corporate sustainability are hard to incorporate into project management frameworks (Narimissa et al., 2020).Furthermore, existing frameworks don't actually give creative answers for managing key objectives of sustainability, for example, fundamentally diminishing carbon outflows and limiting natural impacts while keeping up a permit to work in the public eye. We trust that the consequences of our examination can help project supervisors to design new methodologies so as to enhance sustainability bringing about more accomplishment 
in the project, particularly in new and better-arranged projects utilizing our methodology.The present systems of factors and pointers accessible to measure the general sustainability of business don't bargain successfully with all parts of sustainability at the operational level, particularly in creating nations. These results are limited to just one country and mainly focusing onto the services sector of organizations dealing with projects in Pakistan. Due to aforementioned limitation the results of this research cannot be generalized.

\section{Conclusion}

There is a substantial measure of space for extra research in the zone of sustainability in project management. This examination likewise uncovered that, lately, the quantity of productions about the research topic have grown however stay scattered crosswise over various fields. Moreover, we explored the project managers and responsible personals at project for the project success for these variables by floating a questionnaire and it was concluded that economic, social and environmental dimensions are very important for any project being dealt. The policies made for the TBL constraints if followed can lead the project and organization toward sustainable development. With the help of above findings, the abilities of project managers can be further advanced to check and follow the advanced project management practices and standards which are correlated to sustainable project management.

\section{References}

Aftab, I., Kamal, M., \& Irfan, A. (2020). Mapping Sustainable Development Goal Indicators for Pakistan: Way Forward. Journal of Strategic Innovation and Sustainability, 15(1).

Ahmed, R., \& Anantatmula, V. S. (2017). Empirical study of project managers leadership competence and project performance. Engineering Management Journal, 29(3), 189-205.

Ahuja, J., Panda, T. K., Luthra, S., Kumar, A., Choudhary, S., \& Garza-Reyes, J. A. (2019). Do human critical success factors matter in adoption of sustainable manufacturing practices? An influential mapping analysis of multi-company perspective. Journal of Cleaner Production, 239, 117981.

Al Halbusi, H., Tehseen, S., \& Ramayah, T. C. (2017). The impact of organizational justice on the ethical leadership under the moderating influence of perceived support: A conceptual study. Malaysian Journal of Business and Economics (MJBE).

Al Halbusi, H., Tehseen, S., Hamid, F. A. H., \& Afthanorhan, A. (2018). A Study of Organizational Justice on the Trust in Organization under the Mediating Role of Ethical Leadership.

Alintah-Abel, U. V., Iheama, N. B., \& Ugochukwu, S. C. (2020). Effect of Company Strategies on Organisational Performance in Nigerian Construction Industry. Journal of Engineering Research and Reports, 25-33.

Alvarenga, J. C., Branco, R. R., Guedes, A. L. A., Soares, C. A. P., \& e Silva, W. D. S. (2019). The project manager core competencies to project success. International Journal of Managing Projects in Business. 13 (2), $277-292$. Retrieved from: https://doi.org/10.1108/IJMPB-12-2018-0274

Alvarenga, J. C., Branco, R. R., Guedes, A. L. A., Soares, C. A. P., \& e Silva, W. D. S. (2019). The project manager core competencies to project success. International Journal of Managing Projects in Business. 13 ( 2), 277 292.

Aureli, S., Gigli, S., Medei, R., \& Supino, E. (2020). The value relevance of environmental, social, and governance disclosure: Evidence from Dow Jones Sustainability World Index listed companies. Corporate Social Responsibility and Environmental Management, 27(1), 43-52.

Carvalho, M. M., \& Rabechini Jr, R. (2017). Can project sustainability management impact project success? An empirical study applying a contingent approach. International Journal of Project Management, 35(6), 11201132.

Chow, T. W., Salleh, L. M., \& Ismail, I. A. (2017). Lessons from the major leadership theories in comparison to the competency theory for leadership practice. Journal of Business and Social Review in Emerging Economies, $3(2), 147-156$.

de Melo, J. C. F., Salerno, M. S., Freitas, J. S., Bagno, R. B., \& Brasil, V. C. (2020). From open innovation projects to open innovation project management capabilities: A process-based approach. International Journal of Project Management, 38(5), 278-290. 
Dulewicz, V., \& Higgs, M. (2005). Assessing leadership styles and organizational context. journal of Managerial Psychology.20(2),105-123. https://doi.org/10.1108/02683940510579759

El Garhy, M. S. A. F., Bakr, A. R. M., \& Ibrahim, A. H. (2020). New technologies for interior space and the impact on LEED rating system. International Design Journal, 10(1), 241-247.

Faisal, F. (2017). Sustainability: An Imperative for Improving Governance and Management in Pakistan. Pakistan Economic and Social Review, 55(1), 53-78.

Falqi, I., Alsulamy, S., \& Mansour, M. (2020). Environmental Performance Evaluation and Analysis Using ISO 14031 Guidelines in Construction Sector Industries. Sustainability, 12(5), 1774.

Faul, F., Erdfelder, E., Lang, A. G., Buchner, A., \& Cohen, J. (1988). Statistical power analysis for the behavioral sciences.

Fornell, C., \& Larcker, D. F. (1981). Evaluating structural equation models with unobservable variables and measurement error. Journal of marketing research, 18(1), 39-50.

Gimenez, C., Sierra, V., \& Rodon, J. (2012). Sustainable operations: Their impact on the triple bottom line. International Journal of Production Economics, 140(1), 149-159.

Gomez-Gutierrez, L., \& Cormier, D. (2019). Barriers to worldwide institutionalization of social and environmental disclosure. International Journal of Sustainable Development \& World Ecology, 26(2), 99-112.

Haider, S. A., \& Kayani, U. N. (2020). The impact of customer knowledge management capability on project performance-mediating role of strategic agility. Journal of Knowledge Management. Retrieved from: https://doi.org/10.1108/JKM-01-2020-0026

Hair Jr, J. F., Sarstedt, M., Hopkins, L., \& Kuppelwieser, V. G. (2014). Partial least squares structural equation modeling (PLS-SEM). European business review.

Hair Jr, J. F., Sarstedt, M., Matthews, L. M., \& Ringle, C. M. (2016). Identifying and treating unobserved heterogeneity with FIMIX-PLS: part I-method. European Business Review.

Halbusi, H. A., \& Tehseen, S. (2018). Impact of ethical leadership on affective commitment through mediating impact of ethical climate: A Conceptual study. Durreesamin Journal, 4(2).

Henseler, J., Ringle, C. M., \& Sarstedt, M. (2015). A new criterion for assessing discriminant validity in variancebased structural equation modeling. Journal of the academy of marketing science, 43(1), 115-135.

Hussain, I., Chaudhary, G. M., Arshad, A., \& Akram, S. (2020). Knowledge Management and Sustainable Firms Growth: An Evidence from SMEs Sector of Pakistan. Journal of Business and Social Review in Emerging Economies, 6(3), 1075-1086.

Kock, N. (2017). WarpPLS user manual: Version 6.0. ScriptWarp Systems: Laredo, TX, USA.

Lozano, R., \& Garcia, I. (2020). Scrutinizing sustainability change and its institutionalization in organizations. Frontiers in Sustainability.

Martens, M. L., \& Carvalho, M. M. (2017). Key factors of sustainability in project management context: A survey exploring the project managers' perspective. International Journal of Project Management, 35(6), $1084-1102$. Retrived from: https://doi.org/10.1016/j.ijproman.2016.04.004

Montalbán-Domingo, L., García-Segura, T., Amalia Sanz, M., \& Pellicer, E. (2019). Social sustainability in delivery and procurement of public construction contracts. Journal of management in engineering, 35(2), 04018065.

Narimissa, O., Kangarani-Farahani, A., \& Molla-Alizadeh-Zavardehi, S. (2020). Evaluation of sustainable supply chain management performance: Dimensions and aspects. Sustainable Development, 28(1), 1-12.

Nesticò, A., \& Maselli, G. (2020). Sustainability indicators for the economic evaluation of tourism investments on islands. Journal of Cleaner Production, 248, 119217.

Økland, A. (2015). Gap analysis for incorporating sustainability in project management. Procedia Computer Science, 64, 103-109.

Qureshi, M. A., Kirkerud, S., Theresa, K., \& Ahsan, T. (2020). The impact of sustainability (environmental, social, and governance) disclosure and board diversity on firm value: The moderating role of industry sensitivity. Business Strategy and the Environment, 29(3), 1199-1214. 
Ringle, C. M., Wende, S., \& Becker, J. M. (2015). SmartPLS 3. Boenningstedt: SmartPLS

Rostamnezhad, M., Nasirzadeh, F., Khanzadi, M., Jarban, M. J., \& Ghayoumian, M. (2020). Modeling social sustainability in construction projects by integrating system dynamics and fuzzy-DEMATEL method: a case study of highway project. Engineering, Construction and Architectural Management.

Švajlenka, J., \& Kozlovská, M. (2020). Evaluation of the efficiency and sustainability of timber-based construction. Journal of Cleaner Production, 120835.

Tan, Y., Shuai, C., Shen, L., Hou, L., \& Zhang, G. (2020). A study of sustainable practices in the sustainability leadership of international contractors. Sustainable Development, 28(4), 697-710.

Tehseen, S., Ramayah, T., \& Sajilan, S. (2017). Testing and controlling for common method variance: A review of available methods. Journal of Management Sciences, 4(2), 142-168.

Trivedi, M. (2017). Unit-2 Simple Random Sampling. IGNOU.

Ul Musawir, A., Serra, C. E. M., Zwikael, O., \& Ali, I. (2017). Project governance, benefit management, and project success: Towards a framework for supporting organizational strategy implementation. International Journal of Project Management, 35(8), 1658-1672.

Yu, M., Zhu, F., Yang, X., Wang, L., \& Sun, X. (2018). Integrating sustainability into construction engineering projects: Perspective of sustainable project planning. Sustainability, 10(3), 784.

Zaman, U., Abbasi, S., Nawaz, S., \& Siddique, M. S. (2020). Linking sustainability management and success in construction projects: Moderating influence of high performance work systems. Pakistan Journal of Commerce and Social Sciences (PJCSS), 14(3), 661-684.

Zia-ur-Rehman, M., \& Zia, M. (2020). Framework Based Analysis of Corporate Leadership, Emotional Intelligence (EI) Competencies and Organizational Performance-A Developmental Perspective. Journal of Accounting and Finance in Emerging Economies, 6(2), 427-439. 